\title{
Does the Covid-19 Pandemic Affect the Stock Market in Indonesia?
}

\author{
Dwi Rahmayani, Shanty Oktavilia \\ Department of Development Economics, Faculty of Economics, Universitas Negeri Semarang \\ (email: dwirahmayani@mail.unnes.ac.id)
}

\begin{abstract}
This study aimed to analyze the existence and effect of the Covid-19 pandemic on the stock market over the long-term and short-term in Indonesia. The study followed Krugman's (1979) approach stating the pandemic crisis problems have the potential to decrease the performance of the international balance of payments which will ultimately lead to uncertainty in the market. The research method was the Error Correction Model (ECM) with stock markets as an endogenous variable; and exchange rate, inflation, interest rate, foreign stock markets, commodity price, and pandemic as exogenous variables. The pandemic indicator was measured by total accumulative cases of Covid-19 per day in Indonesia. Using ECM, the result showed that foreign interest rates and commodity prices positively affect the stock markets. Conversely, the exchange rate has a negative effect on the stock markets. However, the estimation fails to reflect the significant impact of the Covid-19 pandemic in the short-term, but it has a negative effect on stock markets in the long-term. This result implies that the higher total accumulative cases of Covid-19 has been the source of Indonesia's stock market weakness in the long-term. To the best of the author's knowledge, this study is the first to examine Indonesia's stock market's pandemic impact between the short term and long term.
\end{abstract}

\section{Keywords:}

Covid-19; error correction model; interest rate; pandemic; stock market

\section{Introduction}

Covid-19, Corona Virus Disease-2019, according to the World Health Organization (2020a), is an infectious disease caused by SARS-CoV-2. World Health Organization (WHO) has established the Covid-19 as a global pandemic that affected many countries on March $12^{\text {th }}, 2020$. WHO (2020b) noticed that Covid-19 spreads between people through direct, indirect (through contaminated objects or surfaces), or close contact with infected people via mouth and nose secretions. These include saliva, respiratory secretions, or secretion droplets. According to Worldometer until May $18^{\text {th }}$, 2020, Covid-19 has spread in 215 countries, with a total of $4,840,960$ cases, 317,367 deaths, 2,648,265 current infected patients, and $1,875,128$ recovered. The ten most-affected countries of Covid-19 per May 18 ${ }^{\text {th }}, 2020$ were the United States, Russia, Spain, Brazil, United Kingdom, Italy, France, Germany, Turkey, and Iran. The United States was the first mostaffected country of Covid-19 by 1,53 million total cases or contributing to $31,65 \%$ of total cases in the world. In contrast, China, where the first cases of Covid-19 were found, was ranked $13^{\text {th }}$ among 215 countries affected, with a total of 82,954 cases.

Indonesia ranked at $33^{\text {rd }}$ of 215 countries with the most number of cases of Covid-19 in the same period. The number of affected Covid-19 in Indonesia per May $18^{\text {th }}, 2020$, was 18,010 cases, 1,191 deaths, and 4,324 patients recovered. The number of new cases in Indonesia has grown per day rapidly. The average growth of the number of accumulated 
Figure 1.

Top Ten Most-Affected Countries of Covid-19

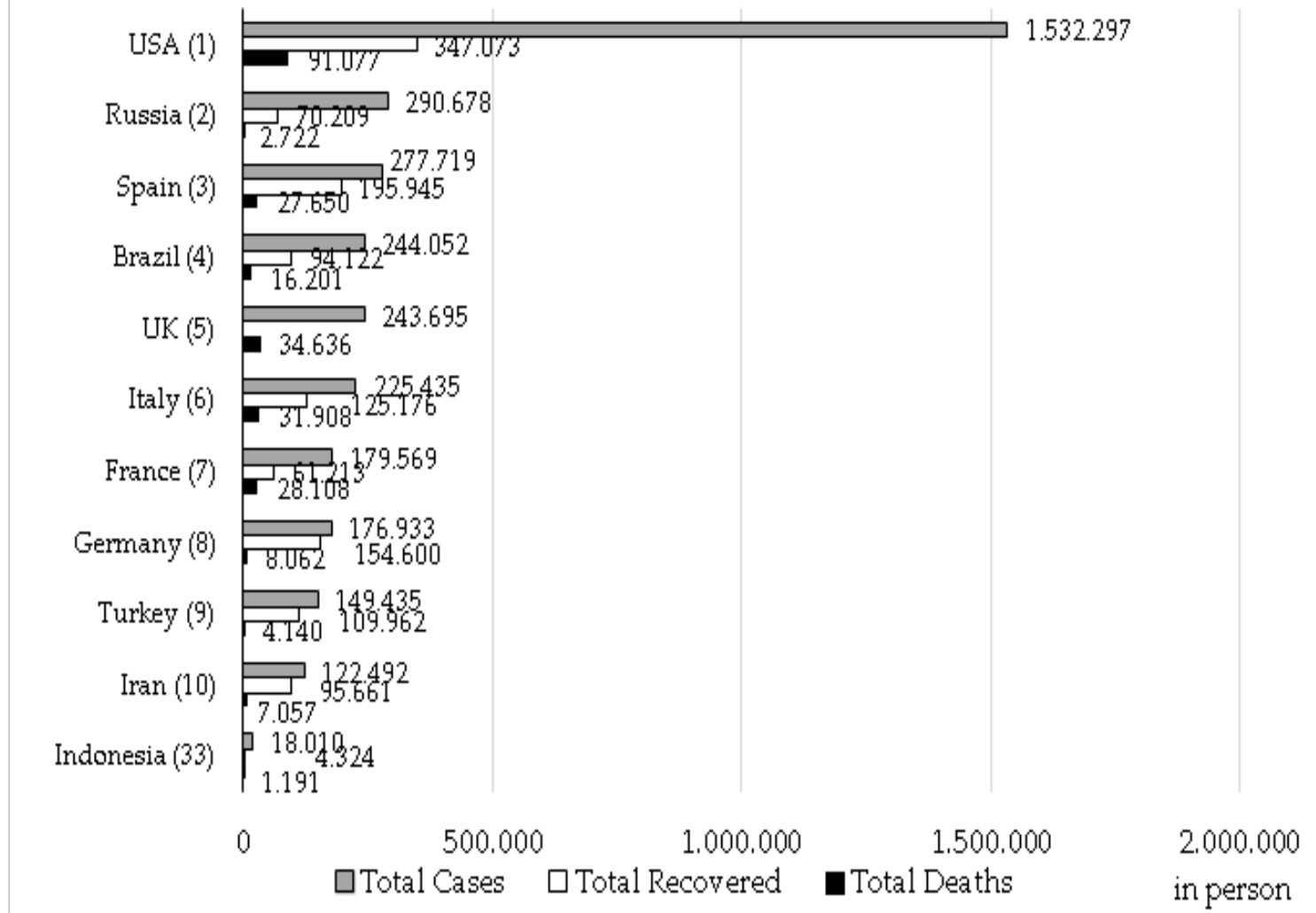

Source: Worldometers, data until Mei 18 ${ }^{\text {th }}, 2020$

cases of Covid-19 in Indonesia was 12,55\% per day. The average growth of recovered patients was $11,77 \%$ per day, while the average increase in the death rate was $9,70 \%$ per day. In the same period, Indonesia was ranked $22^{\text {nd }}$ by the highest number of deaths because of those affected by Covid-19. Indonesia's government has responded to announce that Covid-19 is the non-natural disaster category per March $14^{\text {th }}, 2020$, which needs to be a top priority in various mitigation efforts.

The spreading of the Covid-19 has already impacted many sectors, such as economic, social, bilateral, and multilateral relations among countries. The latest domestic economic indicator's publication by Statistic Center Bureau in Indonesia and other institutions shows it. The economic growth of Indonesia in Quarter I-2020 has dropped by 2,97\% (Year on Year/YoY), lower than the economic growth in Quarter I-2019 of 5,07\% (YoY). Its growth has also decreased by -2,41\% (Quarter to Quarter, Q-to-Q) than Quarter IV-2019, growing by $4,97 \%$ (YoY). Then, the stock market that showed by the Jakarta Stock Composite Index (JKSE) price on May $18^{\text {th }}, 2020$, was IDR 4.511 or decreased around $-28,21 \%$ (Year to Date/ YTD) from January $2^{\text {nd }}, 2020$ by IDR 6.284. The pandemic of Covid-19 also has affected the depreciation of the exchange rate of Rupiah to United States Dollar (USD). The Rupiah's exchange rate decreased around 6,65\% (YTD) to USD in the same period.

In the foreign indicator, the financial market that proxied by the stock market in the United States is getting a shock caused by the pandemic. It shows by the Dow Jones Industrial Average (DJI) reduced price around $-14,80 \%$ (YTD) per May $18^{\text {th }}, 2020$. The other global impact is the price of raw oil as Brent oil dropped deeply by $-47,46 \%$ (YTD) from USD $66,25 /$ barrel on January $2^{\text {nd }}, 2020$, to USD 34,81 / 
barrel on May $18^{\text {th }}, 2020$. It has caused many countries to apply lockdown policies to prevent the spread of coronavirus. It has impacted the oversupply of raw oil stock globally, caused by the low demand from importer countries, then implied dropping of the raw oil price.

Accordingly, Kilian and Park (2009) researched the impact of oil price shocks on the United States' stock market. The results show that the stock return reaction from the oil price shock depends on the oil price change affected by the collapse of demand and supply in the oil market. The model shows that the demand and supply shock driving the global crude oil market joint accounts for $22 \%$ of the long-term variation in U.S. real stock returns.

The priority policies should be carried out immediately by all parties, not only the government but also all stakeholders and society. Over the last five years, Indonesia's average economic growth is only 5,03\% per year. The economy has grown at a stagnant level at around 5\%. The Covid-19 pandemic has created concerns in many countries that they will remain trapped in the recession phase. Indonesia has still depended on foreign investors up to $38 \%$ in the stock market, as the amount of IDR 419,4 trillion, per August $4^{\text {th }}$, 2020. In the same period, the domestic investor has $62 \%$, as the amount of IDR 697,4 trillion contributed to Indonesia's total stock market. Portfolio investment has been driven directly on the performance of multisector in Indonesia. Many investors would sell out the portfolio investment into a safe asset or be replaced into low-risk countries (capital outflow) in uncertain conditions. As an emerging country, Indonesia would have a higher impact if foreign investors left the domestic financial market. There is still limited research to analyze the impact of the Covid-19 pandemic on the stock market, especially in emerging countries.

The economic crisis in this study was approached by Krugman (1979), stating that there would be a potential contagion to the overall economic indicator, which usually appears at the beginning of the financial performance and banking sectors. The pandemic crisis problems have the potential to decrease the performance of the international balance of payments which will ultimately lead to uncertainty in the market. Some of the studies that refer to this opinion include Abbara \& Zevallos (2014); Frankel \& Saravelos (2012); Horn et al. (2020), which states that if the uncertainty of a disaster settlement and/or pandemic is unclear, the potential moral hazard market participants will potentially cause market uncertainty and the global economic crisis. The Covid-19, a global pandemic, causes all countries to make an effort to suppress the increase in the number of new cases. The previous global epidemic had occurred in the $20^{\text {th }}$ century, namely the influenza pandemic. This influenza pandemic infected many countries and occurred three times in a century (years 1918, 1957, and 1968). According to a study by Meltzer et al. (1999) hospitalization data, and outpatient visits, we estimated 89,000 to 207,000 deaths; 314,000 to 734,000 hospitalizations; 18 to 42 million outpatient visits; and 20 to 47 million additional illnesses. Patients at high risk (15\% of the population, an influenza pandemic's estimated economic impact would range from USD 71-166 billion in the United States.

Wulan \& Nurfaiza (2015), using multiple linear regression analysis, results that variable interest rate, money supply, and Rupiah's exchange rate had a significant positive effect on the inflation rate. The other study with the same variables, Yolanda (2017), analyzed the effect of B.I. Rate, foreign exchange rate, money supply, oil price, and gold price on inflation, impact human development index (HDI) and poverty in Indonesia from 1997 up to 2016 . The method used was multiple regression analysis. The result of the study indicated that there were significant variables simultaneously at B.I. Rate, Foreign Exchange Rates, Money Supply, oil 
price, and gold prices to Indonesia's inflation level. The results also showed a variable B.I. Rate, money supply, oil price, and gold prices partially affect inflation positively and significantly, while the exchange rate variable did not affect inflation.

Although many studies have discussed the pandemic impact on the economy, no study has explored the stock market effects of a new global pandemic, Covid-19, in Indonesia. Therefore, this paper aimed to analyze the existence and effect of the Covid-19 pandemic on Indonesia's stock markets, over the longterm and short-term. This study will answer the following questions: (1) Does foreign stock affect Indonesia's stock market?; (2) Does interest rate, both domestic interest rate (Bank Indonesia 7 Day Repo Rate) and foreign interest rate (Effective Federal Funds Rate) affect Indonesia's stock market?; (3) Does the exchange rate affect Indonesia's stock market?; (4) Does domestic inflation affectIndonesia's stock market?; and (5) Does the global commodity market affect Indonesia's stock market? Although many studies have discussed the stock market, no study was found that explored how the pandemic impacted Indonesia's stock market between the short term and long term. This study contributes to the government's strategy to prevent and mitigate the economy dropping into a deep recession. This study also recommends a strategy for government and stakeholders to (i) cooperate and offer a good value proposition for the foreign investor, (ii) raise the rate of ease of doing business, (iii) use the potential of bonus demography optimally.

\section{Literature Review}

The catastrophic impacts of the Covid-19 pandemic cannot be predicted by researchers because this kind of situation is rare and even unprecedented. The use of models that use a fundamental macroeconomic view may be slow to portray the impact that occurs on the market. Alternatively, some research extracts information from asset price behaviors such as stocks, bonds (Harvey, 1989), and credits (Gilchrist \& Zakrajšek, 2012) to identify the market's perspective on the economy due to the Covid-19 pandemic.

Many studies also explored the pandemic's impact on the economy in several countries. In Sweden, Karlsson et al. (2014) analyzed the Spanish flu epidemic's impact in 1918 between short and medium terms economic performance. The study reported that pandemic leads to a significant increase in poor-home levels. The pandemic has also negatively influenced the return of capital. For capital incomes, the pandemic has a strong negative impact, and this impact seems to be a combination of shortand medium-term responses. The pandemic was causing a significant reduction in the quality of life of the average worker. The impact of the Covid-19 pandemic creates a rising unemployment rate in many affected countries. On March 18th, 2020, International Labor Organization (ILO) issued a policy framework consisting of three main pillars to fight the Covid-19 pandemic based on the International Labor Standards. The three components include (i) protecting workers in the workplace, (ii) stimulating the economy and labor demand, and (iii) supporting employment and incomes (ILO, 2020).

Jordà et al. (2020) analyze the long-term economic effects of the pandemic. Significant macroeconomic after-effects of the epidemics persist for about 40 years, with real return rates substantially depressed. In contrast, the finding that wars have no such effect, was indeed the opposite. The result is consistent with the destruction of capital that happens in wars, but not in pandemics. Using more sparse data shows the real wages are somewhat elevated in subsequent epidemics. The findings are consistent with pandemics inducing labor scarcity and a shift to more significant precautionary savings. 
The Covid-19 has spread rapidly in 215 affected countries in the world. Ozili \& Arun (2020) researched the spillover of Covid-19 on the economy globally. Empirically, this study explains the effects of social distancing policies on economic activity and stock market indices. The findings reveal that the increasing number of lockdown days, monetary policy decisions, and international travel restrictions severely affected economic activities and the closing, opening, lowest, and highest stock price of major stock market indices. The opening, the lowest, and the highest stock price was the major stock market indices. In contrast, the imposed restriction on internal movement and higher fiscal policy spending positively impacted economic activities. However, the increasing number of confirmed coronavirus cases did not significantly affect the level of economic activities.

McKibbin \& Fernando (2020)this paper explores seven different scenarios of how COVID-19 might evolve in the coming year using a modelling technique developed by Lee and McKibbin (2003 have explored seven scenarios of how the Covid-19 flourished early in the year. The study described the impact of various macroeconomic outcomes and the financial market in a global hybrid DSGE/CGE general equilibrium model. The paper's scenes demonstrate that even a contained outbreak could significantly impact the global economy in the short-term. These scenarios illustrate the scale of costs that might be avoided by more significant investment in public health systems in all economies, particularly in less developed economies where health care systems are less developed, and population density is high.

\section{Research Methods}

Data

This paper used the secondary database from Indonesia Statistics Central Bureau, Bank Indonesia, Ministry of the Health Republic Indonesia, Yahoo Finance, Investing, and the
Fed. This study uses daily market price data indicated by the endogenous and exogenous variables analyzed. This paper used Stock Markets as an endogenous variable proxied by Jakarta Stock Exchange Composite (JKSE) in Rupiah. On the other side, exogenous variables for this paper used exchange rate (in USD/IDR), interest rate (B.I. 7 Day Repo Rate and Effective Federal Funds Rate/EFFR), inflation (in\%, YoY), foreign stock markets (Dow Jones Industrial Average/DJI in USD), commodity price (raw oil price, i.e., Brent oil in USD/barrel), and pandemic (total cases accumulative of Covid-19 per day in Indonesia). The data set relative to Indonesia, United States, and World with time-series data daily from January $2^{\text {nd }}, 2020$ to October $27^{\text {th }}, 2020$. This paper used an error correction model (ECM) to show the shortterm's effect of the Covid-19 pandemic on the Indonesian stock market.

\section{Empirical and Econometric Model}

First, this paper approached the model from Yolanda (2017) as:

$I N F=f(B I, M S, F R, O I L, G O L D)$

$I N F=\beta_{0}+\beta_{1} I N F+\beta_{2} M S+\beta_{3} F R+B_{4} O I L+$

$\beta_{5} G O L D+e$

where: INF is inflation, B.I. is Rate of Bank Indonesia, MS is Money Supply, F.R. is Foreign Exchange Rates, OIL is oil price world, and GOLD is the gold price. This study was then combined with Krugman's (1979) approach stating the pandemic crisis problems have the potential to decrease the performance of the international balance of payments which will ultimately lead to uncertainty in the market. So, the model was modified with derived the empirical model as:

$$
\begin{aligned}
Y= & f(E R, I R D, I R F, I N F, F S, C P, P D C) \\
& \text { Then, write down as: } \\
Y= & \beta_{1} E R+\beta_{2} I R D+\beta_{3} I R F+\beta_{4} I N F+\beta_{5} F S+ \\
& \beta_{6} C P+\beta_{7} P D C
\end{aligned}
$$


This paper used an error correction model (ECM) to show the pandemic's short-term effect on stock markets. From equation 4 , the econometric model in long-term with ordinary least-squares (OLS) write down as:

$\operatorname{In} Y_{t}=\alpha+\beta_{1} \operatorname{In} E R_{t}+\beta_{2} I R D_{t}+\beta_{3} I R F_{t}+$

$\beta_{4} I N F_{t}+\beta_{5} \operatorname{In} F S_{t}+\beta_{6} \operatorname{InCP} P_{t}+\beta_{7} P D C_{t}+e_{t}$

Then, to show the short-term effect used error correction model (ECM), equation 3 derived as:

$\Delta \operatorname{In} Y_{t}=\alpha_{0}+\beta_{1} \Delta \operatorname{In} E R_{t}+\beta_{2} \Delta I R D_{t}+\beta_{3} \Delta I R F_{t}+$ $\beta_{4} \Delta I N F_{t}+\beta_{5} \Delta \operatorname{In} F S_{t}+\beta_{6} \Delta \operatorname{In} C P_{t}+\beta \Delta P D C_{t}+$ $\gamma e_{t-1}+v_{t}$

Noted that: $\gamma e_{t-1}=e_{t-1}=E C T$

where: $\mathrm{Y}$ is the stock market in Indonesia as an endogenous variable. The exogenous variable was E.R., IRD, IRF, INF, F.S., CP, and PDC. E.R. is the exchange rate, IRD is the domestic interest rate, IRF is the foreign interest rate, INF is domestic inflation, F.S. is foreign stock markets, C.P. is commodity price, and PDC is pandemic, is constant, $\beta_{1}, \beta_{2}$, $\ldots, \beta_{7}$ is the elasticity of exogenous variable, $\mathrm{t}$ is period in day-t, e is an error in the longterm, $\mathrm{v}$ is an error in the short-term, and ECT is error correction term and is the first difference of each variable.

The stock market $(Y)$ was proxied by the Jakarta Stock Exchange Composite (JKSE) in Rupiah. Then, E.R. was proxied by the exchange rate of USD/IDR; IRD was proxied by Bank Indonesia (B.I.) 7-Day Repo Rate; IRF was proxied by Effective Federal Funds Rate (EFFR); INF was proxied by headline inflation in Indonesia (in percent, YoY); F.S. was proxied by Dow Jones Industrial Average (DJI) in USD; commodity price was proxied by raw oil price, i.e., Brent oil in USD/barrel; and the pandemic was proxied by total cases accumulative of Covid-19 per day in Indonesia.
Finally, this paper's last result was identified as the robustness estimates referred to as the Best Linear Unbiased Estimator (BLUE) by the Gauss-Markov Theorem. A study can explain good modeling if there were not some classic assumption problems with the "BLUE" approach. The result of running the data should avoid classic assumption problems such as multicollinearity, autocorrelation, and heteroscedasticity. The first result for the long-term equation with Ordinary Least Squared (OLS) has to get a problem with the autocorrelation and heteroscedasticity. Then to resolve those problems, this research used the covariance method with HAC (Newey-West). The second equation in the short-term with Error Correction Model (ECM) has no problem with classic assumption problems, so it has a robustness model.

\section{Results}

Indonesia reported the first case of Covid-19 in Depok City on March 2 ${ }^{\text {nd }}, 2020$. Initially, the Covid-19 pandemic was poorly noticed by many parties in Indonesia. However, in the first three months, the growth of new cases of people with Covid-19 increased exponentially. The Covid-19 pandemic has caused many sectors to be affected in some countries, both developed and developing countries, including Indonesia. Table. 1, it shows a descriptive statistical summary of some components in the real and financial markets affected by the Covid-19 pandemic.

The first component is stock markets, proxied by Jakarta Stock Exchange Composite (JKSE) and Dow Jones Average Industrial (DJI). The average of JKSE was IDR 5147,43 from January $2^{\text {nd }}, 2020$, to October $27^{\text {th }}, 2020$. The peak position of JKSE was achieved to IDR 6325,41, and the lowest point was IDR 3937,63 on March $24^{\text {th }}, 2020$. It means that the first cases found in early March 2020 impacted decreasing the stock market. At the same time, DJI also dropped USD18.591,93 on March 23 ${ }^{\text {rd }}$, 2020. In contrast, DJI achieved a peak point of 
Table 1.

Summary Statistic Descriptive

\begin{tabular}{|c|c|c|c|c|c|c|c|c|}
\hline & JKSE & $\begin{array}{c}\text { Exchange } \\
\text { Rate } \\
\text { (USD/ } \\
\text { IDR) } \\
\end{array}$ & B.I. 7 Repo & EFFR & Inflation & DJI & Brent Oil & $\begin{array}{c}\text { Total Cases } \\
\text { Covid-19 } \\
\text { Accumulation } \\
\text { in Indonesia }\end{array}$ \\
\hline Mean & 5147.426 & 14660.61 & 4.406566 & 0.439747 & 2.058154 & 26387.64 & 42.60313 & 83929.04 \\
\hline Median & 5067.504 & 14697.00 & 4.500000 & 0.090000 & 1.948810 & 26855.25 & 42.45500 & 27244.50 \\
\hline Maximum & 6325.410 & 16741.00 & 5.000000 & 1.600000 & 2.978616 & 29551.42 & 68.91000 & 392934.0 \\
\hline Minimum & 3937.630 & 13612.00 & 4.000000 & 0.040000 & 1.320000 & 18591.93 & 19.33000 & 0.000000 \\
\hline Std. Dev. & 539.1148 & 710.4900 & 0.363440 & 0.620147 & 0.634469 & 2400.633 & 11.07900 & 111599.4 \\
\hline Skewness & 0.653280 & 0.792054 & 0.309981 & 1.190842 & 0.268896 & -0.942226 & 0.265964 & 1.309084 \\
\hline Kurtosis & 2.835123 & 3.620538 & 1.821871 & 2.487901 & 1.381411 & 3.332045 & 2.892653 & 3.490293 \\
\hline Jarque-Bera & 14.30783 & 23.87931 & 14.62181 & 48.96100 & 23.99967 & 30.20664 & 2.429385 & 58.53533 \\
\hline Probability & 0.000782 & 0.000007 & 0.000668 & 0.000000 & 0.000006 & 0.000000 & 0.296801 & 0.000000 \\
\hline Sum & 1019190. & 2902801. & 872.5000 & 87.07000 & 407.5144 & 5224753. & 8435.420 & 16617950 \\
\hline $\begin{array}{l}\text { Sum Sq. } \\
\text { Dev. }\end{array}$ & 57257010 & 99444809 & 26.02146 & 75.76269 & 79.30252 & $1.14 \mathrm{E}+09$ & 24180.62 & $2.45 \mathrm{E}+12$ \\
\hline Observations & 198 & 198 & 198 & 198 & 198 & 198 & 198 & 198 \\
\hline
\end{tabular}

Source: obtained from secondary data processed, 2020

USD 29.551,42 on February 12 ${ }^{\text {th }}, 2020$, around a month before dropping to the deepest point on March $23^{\text {rd }} 2020$.

Then, the exchange rate of some countries is also recorded as the depreciation caused by Covid-19. The average exchange rate of Rupiah to United States Dollar (USD) was IDR $14.660,61$ in the period from January $2^{\text {nd }}, 2020$, to October $27^{\text {th }}, 2020$. The highest appreciation of the exchange rate (USD/IDR) was IDR 13.612,00, and the deepest depreciation was IDR 16.741,00 on April 2 ${ }^{\text {nd }}, 2020$. The economy being paralyzed has also affected the lower inflation in August 2020 to 1,32\%. It might cause many employees be fired by firms resulting in lower take-home pay. The global impact of massive layoffs dropped the purchasing power of the consumer.

The commodity price proxied by Brent oil dropped in the first quarter of the pandemic phase. The average of Brent oil was USD 42,60 per barrel, and the highest rate was USD 68,91 per barrel on January $6^{\text {th }}, 2020$. The Brent oil price dropped deeply as the pandemic spread rapidly. The lowest price of Brent oil was USD 19,33 per barrel on April 21 ${ }^{\text {th }}, 2020$. It was caused by many countries using a lockdown policy to prevent the spreading of pandemic broadly. It impacted an oversupply of raw oil that caused limited mobility by lockdown policy and dropped demand globally. However, Figure 1 shows that the oil price rebounded quickly, despite being still below the year 2019 .

Third, the domestic interest rate proxied by B.I. 7-Day Repo Rate has an average of $5,4 \%$. The highest interest rate was $6 \%$, and the lowest interest rate was $4,4 \%$. As a central bank in Indonesia, Bank Indonesia has a fast response to keeping the economy growing stable by boosting money's liquidity and the purchasing power of consumers. Bank Indonesia has decreased the interest rate of 100 basis points (bps) from $5 \%$ on January $2^{\text {nd }}, 2020$, to $4,0 \%$ since July $16^{\text {th }} 2020$. Bank Indonesia has followed the Fed's policy responsively to decrease the interest rate at the same time. The Covid-19 pandemic has caused economic paralysis in many countries, including the 
Figure 1.

\section{Economic Indicator}

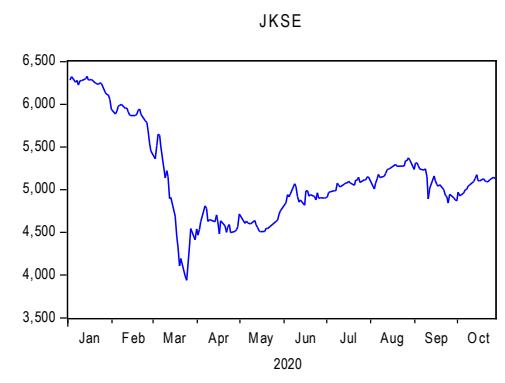

IRF

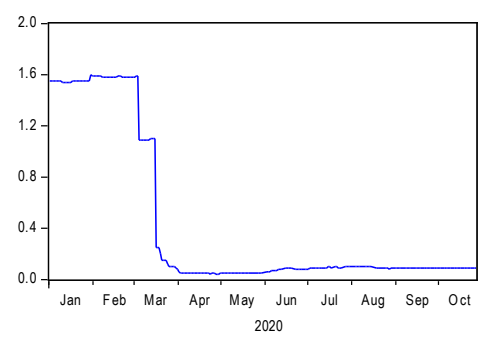

PDC

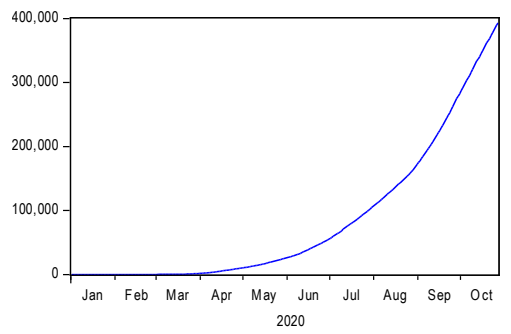

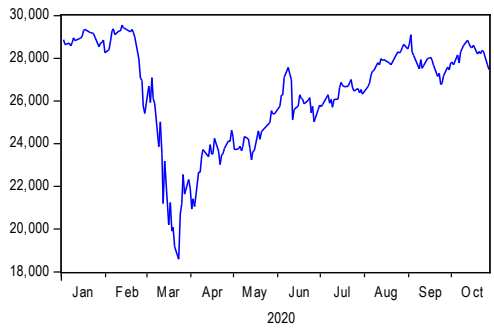

ER

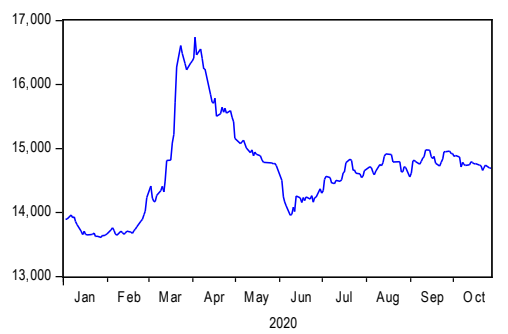

$C P$

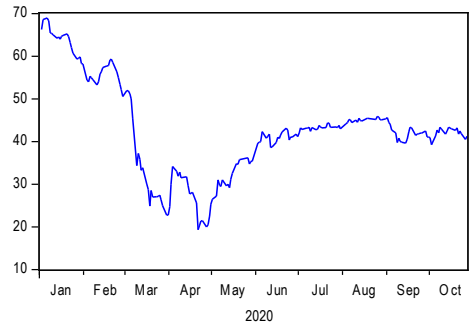

$\operatorname{Ro}$

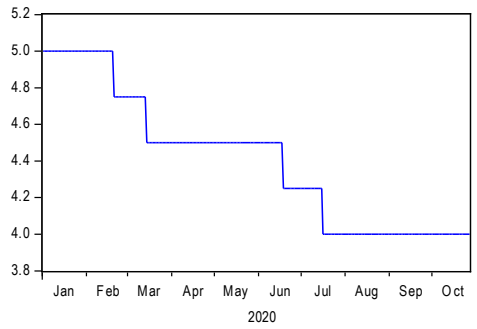

INF

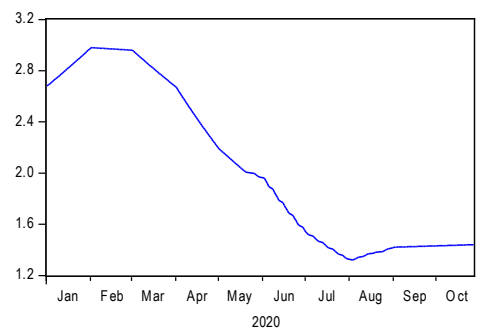

Note: Jakarta Stock Exchange Composite (JKSE), Exchange Rate (E.R.), Interest Rate Domestic (IRD)/B.I. 7 Day Repo Rate, Interest Rate Foreign (IRF)/EFFR, Foreign Stock (F.S.)/ DJI, Commodity Price (C.P.)/Brent Oil, Pandemic (PDC)/Total Cases Accumulation in Indonesia.

Source: data processed with Eviews-10, 2020

United States. The Fed reduced the effective federal funds rate (EFFR) of $146 \mathrm{bps}$, from $1,55 \%$ in January 2020 to 0,09\% until October 2020.

This paper aimed to analyze the effect of the Covid-19 pandemic on the stock market between the long-term and short-term. First, the last result of this study was a robust result, proved with no found classic assumption problem. The result of running the data should avoid classic assumption problems such as multicollinearity, autocorrelation, and heteroscedasticity. Table 3 showed the classical assumption of linear regression for using the time series data in this paper. The first result for the long-term equation with Ordinary Least Squared (OLS) has a problem with the heteroscedasticity, autocorrelation, and multicollinearity. To resolve those problems and get the robustness result in the long-term, this research used the covariance method with HAC (Newey-West).

Second, a unit root test is needed to check the stationary level of each variable. Table 4 showed that almost all variables are stationary at the first difference with the Phillips-Perron test, except for Effective Federal Funds Rate (EFFR) and Total Cases Covid-19 Accumulative in Indonesia (PDC). All variables are significant at a $99 \%$ level of confidence. 
Table 3.

The Gauss-Markov Test for Long-Term Modeling

\begin{tabular}{lccc}
\hline \multicolumn{4}{c}{ Heteroskedasticity Test: Breusch-Pagan-Godfrey } \\
\hline F-statistic & 6.284872 & Prob. F(7,190) & 0.0000 \\
Obs*R-squared & 37.22672 & Prob. Chi-Square(7) & 0.0000 \\
Scaled explained SS & 71.39378 & Prob. Chi-Square(7) & 0.0000 \\
& Breusch-Godfrey & Serial Correlation L.M. Test: & \\
F-statistic & 36.20746 & Prob. F(2,188) & 0.0000 \\
Obs*R-squared & 55.05888 & Prob. Chi-Square(2) & 0.0000 \\
\hline \multicolumn{4}{c}{ Variance Inflation Factors } \\
\hline \multirow{2}{*}{ Variable } & Coefficient & Uncentered & Centered \\
& Variance & VIF & VIF \\
LOG(ER) & 0.008387 & 275291.7 & 6.770802 \\
IRD & 0.000459 & 3199.640 & 21.50987 \\
INF & 0.000191 & 39.18727 & 26.03151 \\
LOG(FS) & 0.000271 & 447.6073 & 38.66583 \\
LOG(CP) & 0.002092 & 77308.45 & 6.848054 \\
PDC & 0.000279 & 1381.996 & 7.398021 \\
C & $9.14 \mathrm{E}-16$ & 6.337602 & 4.040655 \\
\hline
\end{tabular}

Source: data processed with Eviews-10, 2020

Table 4.

Unit Root Test

\begin{tabular}{clccc}
\hline Variable & \multicolumn{1}{c}{ Proxy } & Adj. t-Stat & Prob. & Stationary at \\
\hline Y & Jakarta Stock Exchange Composite (JKSE) & -9.946812 & 0,0000 & $1^{\text {st }}$ Difference \\
ER & Exchange Rate of USD/IDR & -5.925132 & 0,0000 & $1^{\text {st }}$ Difference \\
IRD & BI 7 Day Repo Rate & -14.32689 & 0,0000 & $1^{\text {st }}$ Difference \\
IRF & Effective Federal Funds Rate (EFFR) & -14.15166 & 0,0000 & $2^{\text {nd }}$ Difference \\
INF & Indonesia's inflation & -13.70866 & 0,0000 & $1^{\text {st }}$ Difference \\
FS & Dow Jones Industrial Average (DJI) & -13.33907 & 0,0000 & $1^{\text {st }}$ Difference \\
CP & Brent Oil Price & -9.873752 & 0,0000 & $1^{\text {st }}$ Difference \\
PDC & Total Cases Covid-19 Accumulative in Indonesia & -8.535248 & 0,0000 & $2^{\text {nd }}$ Difference \\
\hline
\end{tabular}

Note: unit root test using the Phillips-Perron test.

Source: data processed by Eviews-10, 2020

Then, Table 5 shows the result obtained using ordinary least squared (OLS) to analyze the long-term effect. First, as can be seen, the interest rate foreign proxied by the Effective Federal Funds Rate (EFFR), the foreign stock proxied by Dow Jones Industrial Average (DJI), and commodity price proxied by Brent oil's price, have positive significance to Indonesia's stock market (JKSE). On the other hand, pandemic (PDC) proxied by total cases accumulative of Covid-19 per day in Indonesia negatively affects Indonesia's stock market (JKSE). Then, the other variable has no significant effect on an endogenous variable, i.e., JKSE.

The interpretation in the long-term modeling would be explained for only the variables that have a significant effect. First, EFFR, DJI's price, and Brent oil's price have a significant positive effect. The interpretation for EFFR was, on average, a $1 \%$ increasein the EFFR would raise Indonesia's stock market (JKSE) by 0,088 in Rupiah. At the same time, on average, a $1 \%$ increase in DJI's price would increase Indonesia's stock market (JKSE) by 0,473 in 
Table 5.

Robustness Estimates of Indonesia's Stock Markets in Long-Term Endogenous Variable: Log JKSE

\begin{tabular}{lllccc}
\hline Variable & Proxy & Coefficient & Standard Error & t-Statistic & Prob. \\
\hline ER & Log ER & 0.221823 & 0.181382 & 1.222963 & 0.2229 \\
IRD & BI 7 DRR & 0.005667 & 0.035454 & 0.159844 & 0.8732 \\
IRF & EFFR & $0.088761^{* * *}$ & 0.021915 & 4.050320 & 0.0001 \\
INF & Inflation & -0.016654 & 0.026335 & -0.632409 & 0.5279 \\
FS & Log DJI & $0.473449^{* * *}$ & 0.068118 & 6.950380 & 0.0000 \\
CP & Log Brent & $0.106838^{* * *}$ & 0.026810 & 3.985042 & 0.0001 \\
PDC & Total Cases Accumulative & $-1.01 \mathrm{E}-07^{* * *}$ & $3.88 \mathrm{E}-08$ & -2.600844 & 0.0100 \\
Constant & & 1.177059 & 1.971299 & 0.597098 & 0.5512 \\
$\mathrm{R}^{2}$ & & 0.948932 & F-statistic & & 504.3602 \\
$\mathrm{R}^{2}$-Adj & 0.947050 & Prop (F-statistic) & & 0.000000 \\
\hline
\end{tabular}

Note: * means significant at a 90\% level of confidence, ** means significance at a 95\% level of confidence, *** means significance at a 99\% confidence level.

Source: Data processed with Eviews-10, 2020

Rupiah. Then, for Brent oil's price means that on average, a $1 \%$ increase in the Brent oil's price would raise Indonesia's stock market (JKSE) by 0,106 in Rupiah.

Second, the pandemic that proxied by total cases accumulated Covid-19 in Indonesia has negative significance to Indonesia's stock market (JKSE) in the long-term. On average, 1 unit increased in the number of cases accumulated. Covid-19 in Indonesia would decrease JKSE by -1.01E-07 in Rupiah. The result indicated that it was consistent with the results obtained in Karlsson et al. (2014) that a pandemic leads to a significant increase in poor-home levels. There is also evidence that the epidemic negatively influences the return of capital. For capital incomes, the pandemic has a strong negative impact, and this impact seems to be a combination of short and medium-term responses. This result also showed that the Covid-19 pandemic would cause economic weakness in the long-term, especially in the stock market sector. The government should have prevented the pandemic, which is spreading rapidly. It also might make the economy paralyzed in the long-term. As an emerging country, Indonesia needs hard work to solve the trade-off between economic stability and health crisis at the same time.
Table 6.

Cointegration Test

\begin{tabular}{cccc}
\hline & $\begin{array}{c}\text { Adj. } \\
\text { t-Stat }\end{array}$ & Prob. & $\begin{array}{c}\text { Stationary } \\
\text { at }\end{array}$ \\
\hline $\begin{array}{c}\text { Phillips- } \\
\text { Perron test } \\
\text { statistic }\end{array}$ & & & Level \\
$\begin{array}{c}\text { Test critical } \\
\text { values: }\end{array}$ & 1\% level & -3.473672 & \\
& $5 \%$ level & -2.880463 & \\
& 10\% level & -2.576939 & \\
\hline
\end{tabular}

Note: unit root test using the Phillips-Perron test.

Source: data processed by Eviews-10, 2020

Table 5, the long-term model, has the robustness estimates with HAC (Newest-West) standard errors \& covariance method. Both processes are used to solve the autocorrelation and heteroskedasticity problems. The goodness of fit model in the long-term showed by $\mathrm{R}^{2}$ Adj of $94,70 \%$. It means that the exogenous variables explained the endogenous variable by $94,70 \%$ in the long-term. F-statistic was also significant at a $99 \%$ level of confidence. It means reject $\mathrm{H} 0$, or all exogenous variables proved to influence the endogenous variable.

Next step, the cointegration test is needed to continue using the error correction model (ECM). The condition to continue to use 
Table 7.

Robustness Estimates of Indonesia's Stock Markets in Short-Term Endogenous Variable: D (Log JKSE)

\begin{tabular}{lllccc}
\hline Variable & Proxy & Coefficient & Standard Error & t-Statistic & Prob. \\
\hline D (E.R.) & D (Log ER) & $-0.493615^{* * *}$ & 0.157925 & -3.125635 & 0.0023 \\
D (IRD) & D (BI 7 DRR) & 0.006738 & 0.029935 & 0.225074 & 0.8224 \\
D (IRF) & D (EFFR) & -0.040365 & 0.025840 & -1.562120 & 0.1215 \\
D (INF) & D (Inflation) & 0.016133 & 0.141882 & 0.113707 & 0.9097 \\
D (F.S.) & D (Log DJI) & $0.214273^{* * *}$ & 0.062492 & 3.428800 & 0.0009 \\
D (C.P.) & D (Log Brent) & $0.057685^{*}$ & 0.032789 & 1.759273 & 0.0817 \\
D (PDC) & D (Total Cases Accumulative) & $6.32 \mathrm{E}-07$ & $8.45 \mathrm{E}-07$ & 0.748371 & 0.4560 \\
ECT & Error Correction Term & $-0.351827^{* * *}$ & 0.082176 & -4.281390 & 0.0000 \\
Constant & & -0.002074 & 0.002017 & -1.028106 & 0.3064 \\
R $^{2}$ & & 0.348466 & F-statistic & & 6.551775 \\
R $^{2}$-Adj & & 0.295279 & Prop (F-statistic) & & 0.000001 \\
\hline
\end{tabular}

Note: ${ }^{*}$ means significant at a $90 \%$ level of confidence, ${ }^{* *}$ indicates significance at a $95 \%$ level of confidence, ${ }^{* * *}$ indicates significance at a 99\% level of confidence.

Source: Data processed with Eviews-10, 2020

the error correction model (ECM) is that the long-term residual was stationary at the unit root level. Table 6 shows the cointegration test of residual from the model in the long-term. It showed that the residual was stationary at the unit root level. It means that the model is valid to continue in the error correction model (ECM).

The short-term effect of the pandemic is shown in Table 7. The result showed that DJI and Brent oil have a significant positive impact on Indonesia's stock market. Both variables are consistent with the long-term model, which positively affects the stock market in Indonesia. The average DJI price increase of $1 \%$ will affect JKSE's price- rise of $0,214 \%$ in the short-term. However, the case is the rise of the Brent oil price by $1 \%$ would only raise the price of JKSE on average by $0,058 \%$. It means that DJI's effects are higher than that of the Brent oil price against JKSE prices. The results of this study follow the implications of the price theory of asset (assets pricing theories), which believes that there is economic shock causing the price of the moving asset, although some research states it is challenging to know which asset price is the first to be influential (Cutler et al., 1989; Gormsen \& Lazarus, 2020).

On the other hand, the exchange rate of Rupiah (USD/IDR) and error correction term (ECT) has negative significance to Indonesia's stock market. It means that, on average, a $1 \%$ increase in the exchange rate of Rupiah would decrease JKSE by $-0,494 \%$. The ECT was measured by residual in the lag-1 (previous period) for a long-term model. The Error Correction Term value (ECT) on the short-term equation indicates significant $(\alpha=$ $5 \%$ ) with a coefficient of $-0,352$. It means that the endogenous variable will adjust its exogenous variable by $35,18 \%$ at one period and reach $100 \%$ in the 2,84 period. A negatively marked value of the ECT coefficient means the primary balance indicates adjustments to instability in the short term. When the ECT coefficient is statistically significant ( $p$-value $=0.0000$ ), it stated that the model specifications used in the study are valid. The Error Correction Model (ECM) will correct the next period if, in the short term, there is an imbalance in one period. 
The short-term model has a different result from a long-term model for the pandemic variable. The total cases accumulated of Covid-19 in Indonesia have no significant effect on Indonesia's stock market in the short-term. In other words, the pandemic has not been economically paralyzed in the short-term, but it will affect the long-term. The other result in the short term is that both the Effective Federal Funds Rate (EFFR) and Brent oil price have no significant effect on Indonesia's stock market.

Table 7, the short-term model, has robustness estimates with no problem in the Gauss-Markov assumption. The goodness of fit model in the short-term showed by $\mathrm{R}^{2}$-Adj of 0,2953 . It means that the exogenous variables can explain the endogenous variable by $29,53 \%$ in the short-term. F-statistic has significance at a $99 \%$ level of confidence. It means reject $\mathrm{H} 0$, or all exogenous variables proved to influence the endogenous variable. Table 8 , the Gauss-Markov test for short-term modeling has proved that the result was the robustness finding with no classical problem indeed. The result of both Heteroskedasticity Test: Breusch-
Pagan-Godfrey and Breusch-Godfrey Serial Correlation L.M. Test were H1 rejected, means that there were no heteroscedasticity and autocorrelation problems. The same condition in the Variance Inflation Factors test showed that VIF in every variable less than 10 . It means there was no multicollinearity in short-term modeling.

This paper showed that the Covid-19 pandemic has no significant effect on the stock market in the short-term but has a negative effect on the long-term. For the first Quarter of 2020, some macro-economic indicator has still shown-up, but lower than the fourth quarter of 2019. Economic growth in Q-I/2020 grew up to $2,97 \%$, lower than in Q-IV/2020 of 4,97\%. Indonesia was trapped in the recession phase in the year 2020. The National Statistic Center Bureau has released the negative economic growth in a two-quarter sequence, i.e., in QII/2020 (-5,32\%) and QIII/2020 (-3,49\%).

The government must apply a policy to prevent and mitigate the economic decline and deep recession, especially on the financial market. First, the government must find ways

Table 8.

The Gauss-Markov Test for Short-Term Modeling

\begin{tabular}{|c|c|c|c|}
\hline \multicolumn{4}{|c|}{ Heteroskedasticity Test: Breusch-Pagan-Godfrey } \\
\hline F-statistic & 1.226814 & Prob. $F(8,98)$ & 0.2916 \\
\hline Obs*R-squared & 9.740363 & Prob. Chi-Square(8) & 0.2837 \\
\hline Scaled explained SS & 22.57627 & Prob. Chi-Square(8) & 0.0040 \\
\hline \multicolumn{4}{|c|}{ Breusch-Godfrey Serial Correlation L.M. Test: } \\
\hline F-statistic & 0.879108 & Prob. $F(2,96)$ & 0.4185 \\
\hline Obs*R-squared & 1.924432 & Prob. Chi-Square(2) & 0.3820 \\
\hline \multicolumn{4}{|c|}{ Variance Inflation Factors } \\
\hline \multirow{2}{*}{ Variable } & Coefficient & Uncentered & Centered \\
\hline & Variance & VIF & VIF \\
\hline $\mathrm{D}(\mathrm{LOG}(\mathrm{ER}))$ & 0.024940 & 1.035819 & 1.004541 \\
\hline $\mathrm{D}(\mathrm{IRD})$ & 0.000896 & 1.045760 & 1.016440 \\
\hline $\mathrm{D}(\mathrm{IRF})$ & 0.000668 & 1.079236 & 1.066618 \\
\hline $\mathrm{D}(\mathrm{INF})$ & 0.020131 & 1.495576 & 1.140144 \\
\hline $\mathrm{D}(\mathrm{LOG}(\mathrm{FS}))$ & 0.003905 & 1.363230 & 1.349101 \\
\hline $\mathrm{D}(\mathrm{LOG}(\mathrm{CP}))$ & 0.001075 & 1.345526 & 1.341938 \\
\hline $\mathrm{D}((\mathrm{PDC}))$ & 7.14E-13 & 2.080002 & 1.112546 \\
\hline RES(-1) & 0.006753 & 1.083797 & 1.083779 \\
\hline C & 4.07E-06 & 2.709061 & NA \\
\hline
\end{tabular}

Source: data processed with Eviews-10, 2020 
to cooperate and offer a good value proposition for foreign investors. The government has to reduce some regulations at all department levels, especially for investment. Second, it is essential to raise the ease of doing business to give a strong signal to the foreign investor. Third, the pandemic is changing how investors make supply chain decisions, so make sure to use the potential of bonus demography optimally. The government has to make sure foreign investors can replace and build their factory in Indonesia to have more capacity and capability in labor, capital, and other resources.

The novelty of this study is using daily market price data indicated by those variables analyzed. This research shows empirical results that Indonesia could potentially experience periods of economic and financial difficulties caused by the Covid-19 pandemic.

\section{Discussion}

This paper aimed to analyze the existence and effect of the Covid-19 pandemic on the stock market in Indonesia between the longterm and short-term. The result of this study finds that in the long-term, the foreign interest rate (EFFR), foreign stock markets (DJI), and commodity price (Brent oil) has a significant positive effect on the stock market in Indonesia (JKSE). On the contrary, domestic inflation and the pandemic (total cases accumulative in Indonesia) have a significant negative effect on Indonesia's stock market. The result indicated that it is consistent with the results obtained in previous studies.

The economic crisis in this study was approached by Krugman (1979), stating that there would be a potential contagion to the overall economic indicator, which usually appears at the beginning of the financial performance and banking sectors. The pandemic crisis problems have the potential to decrease the performance of the international balance of payments which will ultimately lead to uncertainty in the market. Some of the studies that refer to this opinion include Abbara \& Zevallos (2014); Frankel \& Saravelos (2012); Horn et al. (2020), which states that if the uncertainty of a disaster settlement and or pandemic is unclear, the potential moral hazard market participants will potentially cause market uncertainty and the global economic crisis.

This result showed that the Covid-19 pandemic would cause economic weakness in the long-term, especially in the stock market sector. However, the short-term model has a different result from a long-term model for the pandemic variable. The total cases accumulated of Covid-19 in Indonesia have no significant effect on Indonesia's stock market in the shortterm. In other words, the economy has not been paralyzed by the pandemic in the short-term, but it affects the long-term. The other difference from the long-term model was that both the foreign interest rate and domestic inflation has no significant effect on Indonesia's stock market. While there was a new variable that has a significant negative impact on the stock market in Indonesia, i.e., the exchange rate (USD/IDR), then, both the foreign stock (DJI) and commodity price (Brent oil) were the same in the long-term model that has a significant positive effect on Indonesia's stock market.

The government should have prevented the pandemic, which is spreading rapidly. It might make the economy paralyzed in the long-term. Indonesia needs hard work to solve the trade-off between economic stability and health crisis as an emerging country. The government has to apply policy to prevent and mitigate the economic impact and deep recession, especially on the financial market. First, the government must find ways to cooperate and offer a good value proposition for foreign investors. The government has to reduce some regulations at all level departments, especially for investment. Second, it is essential to raise the ease of doing business to give a strong signal to the foreign investor. The third, 
pandemic is changing how investors make supply chain decisions, so make sure to use the potential of bonus demography optimally. The government has to make sure foreign investors can replace and build their factory in Indonesia to have more capacity and capability in labor, capital, and other resources.

\section{Conclusion}

This paper aimed to analyze the existence and effect of the Covid-19 pandemic on the stock market in Indonesia between the long-term and short-term. This study also answered the following questions: (1) Do foreign stocks affect Indonesia's stock market?; (2) Do interest rates, both domestic interest rate (Bank Indonesia 7 Day Repo Rate) and foreign interest rate (Effective Federal Funds Rate) affect Indonesia's stock market?; (3) Does the exchange rate affect Indonesia's stock market?; (4) Does domestic inflation affectIndonesia's stock market?; and (5) Does the global commodity market affect Indonesia's stock market?

Using ECM, the result in the short-term showed that both foreign stock market (DJI) and global commodity price (Brent oil) has a significant positive effect on Indonesia's stock market (JKSE). On the contrary, the exchange rate has a significant negative effect on Indonesia's stock market. The other variables, like domestic and foreign interest rate, inflation, and total cases accumulative of Covid-19, have no significant effect on Indonesia's stock market in the short-term. In the long term, foreign interest rate (EFFR), foreign stock (DJI), and global commodity price (Brent oil) have a significant positive effect on Indonesia's stock market. On the contrary, the only total cases accumulative of Covid-19 has a significant negative effect on Indonesia's stock market. Then the others, exchange rate, domestic interest rate (BI 7 DRR), and inflation have no significant effect on Indonesia's stock market.

However, the estimation fails to reflect the significant impact of the Covid-19 pandemic in the short-term, but it has a negative effect on stock markets in the long-term. This result implies that given higher total accumulative cases of Covid-19 has been the source of Indonesia's stock market weakness in the longterm, especially in the stock market sector. The short-term model has a different result from a long-term model for the pandemic variable. The total cases accumulated of Covid-19 in Indonesia have no significant effect on Indonesia's stock market in the short-term. In other words, the economy has not been paralyzed in the shortterm, but it affects the long-term.

However, the limitation of this study is the cases of Covid-19 are still happening beyond when this paper was finished. The impact of the Covid-19 pandemic on Indonesia's stock market was not covered for all periods. This study considers the contribution to give a strategy for the government to prevent and mitigate the economy from dropping into a deep recession. The recommendation from this study is to give a strategy for government and stakeholders to (i) cooperate and offer a good value proposition for the foreign investor, (ii) raise the rate of ease of doing business, (iii) use the potential of bonus demography optimally.

\section{References}

Abbara, O., \& Zevallos, M. (2014). Assessing stock market dependence and contagion. Quantitative Finance, 14(9), 1627-1641. https://doi.org/10.1080/14697688.2013.8 59390

Cutler, D. M., Poterba, J. M., \& Summers, L. H. (1989). What moves stock prices? In The Journal of Portfolio Management (Vol. 15, Issue 3). https://doi.org/10.3905/ jpm.1989.409212

Frankel, J., \& Saravelos, G. (2012). Can leading indicators assess country vulnerability? Evidence from the 2008-09 global financial crisis. Journal of International Economics, 87(2), 216-231. https://doi.org/10.1016/j. jinteco.2011.12.009 
Gilchrist, S., \& Zakrajšek, E. (2012). Credit Spreads and Business Cycle Fluctuations. American Economic Review, 102(4), 1692-1720. https://doi.org/10.1257/ aer.102.4.1692

Gormsen, N. J., \& Lazarus, E. (2020). DurationDriven Returns. University of Chicago, Becker Friedman Institute for Economics Working Paper No. 2020-22., May. https://papers.ssrn.com/sol3/papers. cfm?abstract_id $=3555917$

Harvey, C. R. (1989). Forecasts of Economic Growth from the Bond and Stock Markets. Financial Analysts Journal, 45(5), 38-45. https://doi.org/10.2469/faj.v45.n5.38

Horn, S., Reinhart, C., \& Trebesch, C. (2020). Coping with disasters: Lessons from two centuries of international response. Vox CEPR Policy Portal, June 9th. https://voxeu. org/article/coping-disasters-lessons-twocenturies-international-response.

International Labor Organization. (2020). COVID-19 and the world of work: Impact and policy responses (Issue March). http://hdl. voced.edu.au/10707/533608

Jordà, Ò., Singh, S. R., \& Taylor, A. M. (2020). Longer-Run Economic Consequences of Pandemics. Federal Reserve Bank of San Francisco, Working Paper Series, 01-16. https://doi.org/10.24148/wp2020-09

Karlsson, M., Nilsson, T., \& Pichler, S. (2014). The impact of the 1918 Spanish flu epidemic on economic performance in Sweden. An investigation into the consequences of an extraordinary mortality shock. Journal of Health Economics, 36(1), 1-19. https://doi. org/10.1016/j.jhealeco.2014.03.005

Kilian, L., \& Park, C. (2009). The impact of oil price shocks on the U.S. stock market. International Economic Review, 50(4), 1267-1287.https://doi.org/10.1111/j.14682354.2009.00568.x

Krugman, P. (1979). A Model of Balance-ofPayments Crises. Journal of Money, Credit and Banking, 11(3), 311-325. http://www. jstor.org/stable/1991793

McKibbin, W. J., \& Fernando, R. (2020). The Global Macroeconomic Impacts of COVID-19: Seven Scenarios. SSRN Electronic Journal, March, 1-43. https://doi. org/10.2139/ssrn.3547729

Meltzer, M. I., Cox, N. J., \& Fukuda, K. (1999). The economic impact of pandemic influenza in the United States: Priorities for intervention. Emerging Infectious Diseases, 5(5), 659-671. https://doi.org/10.3201/ eid0505.990507

Ozili, P. K., \& Arun, T. (2020). Spillover of COVID-19: Impact on the Global Economy. SSRN Electronic Journal, November. https:// doi.org/10.2139/ssrn.3562570

World Health Organization. (2020a). QEA on coronaviruses (COVID-19). WHO. https:// www.who.int/news-room/q-a-detail/q-acoronaviruses

World Health Organization. (2020b). Transmission of SARS-CoV-2 : implications for infection prevention precautions (Issue 9 July). https://www.who.int/publications/i/ item/modes-of-transmission-of-viruscausing-covid-19-implications-for-ipcprecaution-recommendations

Worldometers. (2020). Coronavirus Update (Live): Cases and Deaths from COVID-19 Virus Pandemic. Worldometers. https://www.worldometers.info/ coronavirus/\#countries

Wulan, E. R., \& Nurfaiza, S. (2015). Analysis of Factors Affecting Inflation in Indonesia: an Islamic Perspective. International Journal of Nusantara Islam, 2(2), 67-80. https://doi.org/10.15575/ijni.v2i2.149

Yolanda, Y. (2017). Analysis of factors affecting inflation and its impact on human development index and poverty in Indonesia. European Research Studies Journal, 20(4), 38-56. https://doi. org/10.35808/ersj/873 